\title{
The Virulence Factors of the Bacterial Wilt Pathogen Ralstonia solanacearum
} Fanhong Meng*

Boyce Thompson Institute for Plant Research, 533 Tower Rd, Ithaca, NY 14853, USA

\begin{abstract}
The bacterium Ralstonia solanacearum causes bacterial wilt on more than 200 plant species, including important crops such as potato, tomato, eggplant, pepper, tobacco and banana. Many factors contribute to the virulence of this pathogen. This review discusses the major virulence factors, including extracellular polysaccharide I, the type III secretion system and effectors, swimming motility and twitching motility, cell-wall-degrading enzymes and type II secretion system, and their contribution to the virulence and pathogenicity of Ralstonia solanacearum.
\end{abstract}

Keywords: Ralstonia solanacearum; Bacterial wilt; Virulence factor; Extracellular polysaccharide; T3SS; Motility

Ralstonia solanacearum, previously named Pseudomonas solanacearum and Burkholderia solanacearum, is a soil-borne gramnegative bacterium that causes bacterial wilt disease on more than 200 plant species from 50 botanical families, including important crops such as potato, tomato, eggplant, pepper, tobacco and banana $[1,2] . R$. solanacearum is considered a species complex-a heterogeneous group of related but genetically distinct strains [3]. This bacterium infects plants through root wounds or at sites of secondary root emergence, then colonizes the xylem vessels and spreads rapidly to aerial parts of the plant through the vascular system. In xylem vessels, the bacterial population can multiply extensively and rapidly reach very high levels $\left(>10^{10}\right.$ cells $/ \mathrm{cm}$ of stem in tomato) [4,5]. Typical disease symptoms include browning of the xylem, chlorosis, stunting, wilting, and the infected plants usually die rapidly. Bacterial wilt is considered one of the most destructive bacterial plant diseases because of its extreme aggressiveness, world-wide geographic distribution, and unusually broad host range [6]. In fact, $R$. solanacearum was ranked $2^{\text {nd }}$ in a list of the top 10 most scientifically/economically important plant pathogenic bacterial pathogens in 2012 [7].

$R$. solanacearum has been widely accepted as a model organism for the study of bacterial virulence and pathogenicity in plants [1]. To date, many factors have been found to contribute to the virulence of $R$. solanacearum, however, due to the limited space, this paper will only discuss the major virulence factors in this pathogen.

\section{Extracellular Polysaccharide I (EPS I)}

One of the most important virulence factors is a heterogeneous polymer of $\mathrm{N}$-acetylated extracellular polysaccharide I (EPS I) [8]. EPS I-deficient mutants are nearly avirulent and do not colonize plant xylem vessels as efficient as wild type [4,9]. It has been suggested that EPS I directly causes wilting by physically blocking the vascular system and thereby alters water movement [8]. It has also been hypothesized that EPS protects $R$. solanacearum from plant antimicrobial defenses by cloaking bacterial surface features that could be recognized by hosts $[4,9]$. Interestingly, it has been recently found that $R$. solanacearum EPS I plays different roles in resistant and susceptible hosts [10]. In susceptible tomato plants, the wild-type and EPS I-deficient mutant induced generally similar defense responses; but in resistant tomato plants, the wild-type induced significantly greater defense responses than the EPS I-deficient mutants, suggesting that the EPS I itself is a specific elicitor of plant defense responses [10].

\section{The Type III Secretion System}

The Type III Secretion System (T3SS) has a central role in pathogenesis of many bacterial pathogens of plants and animals [11]. In $R$. solanacearum, the T3SS is encoded by the hrp gene cluster, which spans a $23-\mathrm{kb}$ region on the mega plasmid [12]. As in other major groups of Gram-negative bacteria, $R$. solanacearum hrp genes are key determinants for disease development on compatible hosts and for induction of the defensive hypersensitive response (HR) on resistant plants [13]. $R$. solanacearum is estimated to produce $70-80$ type III effectors [14]. The completely nonpathogenic phenotype of $R$. solanacearum T3SS-defective mutants illustrates the collective importance of the effector proteins that are injected into plant cells by the system, although mutants lacking single effectors are usually fully virulent $[11,15]$. The T3SS of $R$. solanacearum contributes greatly to pathogenesis, but hrp mutants retain the ability to invade tomato roots and systemically colonize the vascular system, although the population size of T3SS mutants in infected tissues was reduced by 10 to 1000 fold compared to wild-type strains $[16,17]$. Recently, in planta transcriptome study and qRT-PCR tests by Jacobs et al. [18] and in planta expression study using green fluorescent protein reporter fusions by Monterio et al. [19] found that the T3SS is still active even after $R$. solanacearum has taken over the xylem, suggesting that the T3SS is functional throughout disease. These results changed the wide spread view from in vitro studies that T3SS is only active at the first stage of infection and is not needed when bacteria reach high cell densities [20,21].

\section{Motility}

R. solanacearum possesses flagella-driven swimming motility and type IV pili-driven twitching motility that are important to its ecological fitness and virulence [22-25]. Both nonmotile and nontactic mutants are significantly reduced in virulence on soil-drench inoculated tomato plants but exhibit normal virulence when directly inoculated into plant xylem, indicating that $R$. solanacearum needs directed motility and that

*Corresponding author: Fanhong Meng, Boyce Thompson Institute for Plant Research, 533 Tower Rd, Ithaca, NY 14853, USA, Tel: +(607) 220 9610; E-mail: fm352@cornell.edu

Received February 12, 2013; Accepted March 25, 2013; Published March 30 , 2013

Citation: Meng F (2013) The Virulence Factors of the Bacterial Wilt Pathogen Ralstonia solanacearum. J Plant Pathol Microb 4: 168 doi:10.4172/21577471.1000168

Copyright: (c) 2013 Meng F. This is an open-access article distributed under the terms of the Creative Commons Attribution License, which permits unrestricted use, distribution, and reproduction in any medium, provided the original author and source are credited. 
swimming motility contributes to virulence in the early stage of host colonization and invasion [22,23]. However, when $R$. solanacearum grows in plant xylem, virtually all the bacterial cells are nonmotile $[22,23]$. Interestingly, recently it is reported that a hypermotile mot $N$ mutant of $R$. solanacearum is also reduced in virulence [26], indicating the importance of precise regulation of motility in this bacterium. $R$. solanacearum strains with mutations in pilQ, pilT or pliA lost twitching

soil-drench and cut-petiole inoculation [24,25]. Furthermore, the pilA mutant was also affected in biofilm formation, adherence to multiple surfaces and natural transformation [24]. Together, these results demonstrate that type IV pili and twitching motility are important for several stages of wilt disease development.

\section{Cell-Wall-Degrading Enzymes (CWDEs) and Type II Secretion System (T2SS)}

R. solanacearum secretes several CWDEs, including three polygalacturonases (PehA , PehB and PehC) $[27,28]$, an endoglucanase (Egl) [29], a pectin methylesterase (Pme) [30], and a cellobiohydrolase (CbhA) [31]. Gene disruption analysis revealed that Egl, PehA, PehB and CbhA, each contribute to the pathogen's ability to cause wilt [3133]. An R. solanacearum strain GMI1000 pyramid mutant lacking all known CWDE genes, although significantly less virulent than parent strain GMI1000, was more virulent than a T2SS mutant. This suggests that additional extracellular proteins secreted by the T2SS contribute to the virulence of $R$. solanacearum [31].

\section{Other Virulence Factors}

Besides the above mentioned virulence factors, $R$. solanacearum also has other factors that contribute to its virulence. For example, $R$. solanacearum encounters reactive oxygen species (ROS) during bacterial wilt pathogenesis and expresses diverse oxidative stress response genes to detoxify ROS or otherwise tolerate this oxidative environment [34-36]. Inactivation of $o x y R$, which encodes the only identified regulator of oxidative stress gene in $R$. solanacearum significantly reduced virulence [37]. Two genes, acrA and $\operatorname{dinF}$, encoding multidrug efflux pumps, were also found to contribute to bacterial wilt virulence [38]. Some metabolic pathways also appear to be required during pathogenesis of $R$. solanacearum, and deletion of metER methionine biosynthesis genes produced significantly reduced disease symptoms without causing auxotrophy or affecting growth inside the plant $[39,40]$. R. solanacearum was also found to need Flp pili for virulence on potato [41].

The virulence factors of $R$. solanacearum are controlled by a complex regulatory signal transduction pathway that responds to both environmental signals and quorum sensing molecule 3-hydroxypalmitic acid methyl ester (3-OH PAME) [20,42]. For details, the readers are referred to a very comprehensive review on regulation of virulence and pathogenicity genes written by Schell [43]. Over the years, substantial progress has been made in studying $R$. solanacearum and bacterial wilt disease [43]. With genomes of more than 10 strains from $R$. solanacearum species complex being available now [4450], our knowledge about this pathogen will be broadened further. Based on comparative genomic analysis of eight sequenced strains, it has been proposed that the $R$. solanacearum core genome comprises $\sim 2,850$ conserved genes, whereas the variable genome contains $\sim 3,100$ genes and the numbers of strain-specific genes vary from strain to strain $[46,47]$. This great genetic variation may account for the broad host range of $R$. solanacearum species complex and makes it more challenging to determine which genes are responsible for host-range speciation. A better understanding of the $R$. solanacearum virulence factors and their complex regulation will lead to novel avenues for research and effective disease control strategies.

\section{References}

1. Hayward AC (1991) Biology and epidemiology of bacterial wilt caused by Pseudomonas solanacearum. Annu Rev Phytopathol 29: 65-87.

3. Fegan M, Prior $\mathrm{P}$ (2005) How complex is the "Ralstonia solanacearum species complex?" In: Allen C, Prior P, Hayward AC, editors. Bacterial Wilt Disease and the Ralstonia solanacearum species complex. St. Paul, MN: APS Press, 449-461.

4. Araud-Razou I, Vasse J, Montrozier H, Etchebar C, Trigalet A (1998) Detection and visualization of the major acidic exopolysaccharide of Ralstonia solanacearum and its role in tomato root infection and vascular colonization. Eur J Plant Pathol 104: 795-809.

5. Vasse J, Frey P, Trigalet A (1995) Microscopic studies of intercellular infection and protoxylem invasion of tomato roots by Pseudomonas solanacearum. Mol Plant Microbe Interact 8: 241-251.

6. Prior P, Allen C, Elphinstone JG (1998) Bacterial Wilt Disease: Molecular and Ecological Aspects. Berlin: Springer Verlag.

7. Mansfield J, Genin S, Magori S, Citovsky V, Sriariyanum M, et al. (2012) Top 10 plant pathogenic bacteria in molecular plant pathology. Mol Plant Pathol 13 . 614-629.

8. Denny TP, Baek SR (1991) Genetic evidence that extracellular polysaccharide is a virulence factor of Pseudomonas solanacearum. Mol Plant-Microbe Interact 4: 198-206.

9. Saile E, McGarvey JA, Schell MA, Denny TP (1997) Role of extracellular polysaccharide and endoglucanase in root invasion and colonization of tomato plants by Ralstonia solanacearum. Phytopathology 87: 1264-1271.

10. Milling A, Babujee L, Allen C (2011) Ralstonia solanacearum extracellular polysaccharide is a specific elicitor of defense responses in wilt-resistant tomato plants. PloS One 6: e15853.

11. Cornelis GR, Van Gijsegem F (2000) Assembly and function of type III secretory systems. Annu Rev Microbiol 54: 735-774.

12. Van Gijsegem F, Gough C, Zischek C, Niqueux E, Arlat M, et al. (1995) The hrp gene locus of Pseudomonas solanacearum, which controls the production of a type III secretion system, encodes eight proteins related to components of the bacterial flagellar biogenesis complex. Mol Microbiol 15: 1095-1114.

13. Boucher CA, Barberis PA, Trigalet A, Demery DA (1985) Transposon mutagenesis of Pseudomonas solanacearum: isolation of Tn5-induced avirulent mutants. Microbiology 131: 2449-2457.

14. Genin S, Boucher C (2004) Lessons learned from the genome analysis of Ralstonia solanacearum. Annu Rev Phytopathol 42: 107-134.

15. Büttner D, Bonas U (2002) Getting across--bacterial type III effector proteins on their way to the plant cell. EMBO J 21: 5313-5322.

16. Etchebar C, Trigalet-Demery D, Gijsegem Fv, Vasse J, Trigalet A (1998) Xylem colonization by an HrcV-mutant of Ralstonia solanacearum is a key facto for the efficient Biological control of tomato bacterial wilt. Mol Plant Microbe Interact 11: 869-877.

17. Vasse J, Genin S, Frey P, Boucher C, Brito B (2000) The hrpB and hrpG regulatory genes of Ralstonia solanacearum are required for different stages of the tomato root infection process. Mol Plant Microbe Interact 13: 259-267.

18. Jacobs JM, Babujee L, Meng F, Milling A, Allen C (2012) The in planta transcriptome of Ralstonia solanacearum: conserved physiological and virulence strategies during bacterial wilt of tomato. mBio 3: e00114-12.

19. Monteiro F, Genin S, van Dijk I, Valls M (2012)A luminescent reporter evidences active expression of Ralstonia solanacearum type III secretion system genes throughout plant infection. Microbiology 158: 2107-2116. 
Citation: Meng F (2013) The Virulence Factors of the Bacterial Wilt Pathogen Ralstonia solanacearum. J Plant Pathol Microb 4: 168 doi:10.4172/21577471.1000168

20. Genin S, Brito B, Denny TP, Boucher C (2005) Control of the Ralstonia solanacearum Type III secretion system (Hrp) genes by the global virulence regulator PhcA. FEBS Lett 579: 2077-2081.

21. Yoshimochi T, Hikichi Y, Kiba A, Ohnishi K (2009) The global virulence regulator PhcA negatively controls the Ralstonia solanacearum hrp regulatory cascade by repressing expression of the PrhIR signaling proteins. J Bacteriol 191: 34243428.

22. Tans-Kersten J, Brown D, Allen C (2004) Swimming motility, a virulence trait of Ralstonia solanacearum, is regulated by FIhDC and the plant host environment. Mol Plant Microbe Interact 17: 686-695.

23. Tans-Kersten J, Huang H, Allen C (2001) Ralstonia solanacearum needs Motility for invasive virulence on tomato. J Bacteriol 183: 3597-3605.

24. Kang Y, Liu H, Genin S, Schell MA, Denny TP (2002) Ralstonia solanacearum requires type 4 pili to adhere to multiple surfaces and for natural transformation and virulence. Mol Microbiol 46: 427-437.

25. Liu H, Kang Y, Genin S, Schell MA, Denny TP (2001) Twitching motility of Ralstonia solanacearum requires a type IV pilus system. Microbiology 147 3215-3229.

26. Meng F, Yao J, Allen C (2011) A MotN mutant of Ralstonia solanacearum is hypermotile and has reduced virulence. J Bacteriol 193: 2477-2486.

27. Huang Q, Allen C (1997) An exo-poly-alpha-D-galacturonosidase, PehB, is required for wild-type virulence of Ralstonia solanacearum. J Bacteriol 179 7369-7378.

28. Schell MA, Roberts DP, Denny TP (1988) Analysis of the Pseudomonas solanacearum polygalacturonase encoded by pglA and its involvement in phytopathogenicity. J Bacteriol 170: 4501-4508.

29. Roberts DP, Denny TP, Schell MA (1988) Cloning of the egl gene of Pseudomonas solanacearum and analysis of its role in phytopathogenicity. J Bacteriol 170: 1445-1451.

30. Tans-Kersten J, Guan Y, Allen C (1998) Ralstonia solanacearum pectin methylesterase is required for growth on methylated pectin but not for bacterial wilt virulence. Appl Environ Microbiol 64: 4918-4923.

31. Liu H, Zhang S, Schell MA, Denny TP (2005) Pyramiding unmarked deletions in Ralstonia solanacearum shows that secreted proteins in addition to plant cell-wall-degrading enzymes contribute to virulence. Mol Plant Microbe Interact 18: $1296-1305$

32. Huang Q, Allen C (2000) Polygalacturonases are required for rapid colonization and full virulence of Ralstonia solanacearum on tomato plants. Physiol Mol Plant Pathol 57: 77-83

33. Denny TP, Carney B, Schell M (1990) Inactivation of multiple virulence genes reduces the ability of Pseudomonas solanacearum to cause wilt symptoms. Mol Plant Microbe Interact 3: 293-300

34. Brown DG, Allen C (2004) Ralstonia solanacearum genes induced during growth in tomato: an inside view of bacterial wilt. Mol Microbiol 53: 1641-1660.

35. Flores-Cruz Z, Allen C (2009) Ralstonia solanacearum encounters an oxidative environment during tomato infection. Mol Plant Microbe Interact 22: 773-782.

36. Colburn-Clifford JM, Scherf JM, Allen C (2010) Ralstonia solanacearum Dps contributes to oxidative stress tolerance and to colonization of and virulence on tomato plants. Appl Environ Microbiol 76: 7392-7399.

37. Flores-Cruz Z, Allen C (2011) Necessity of OxyR for the hydrogen peroxide stress response and full virulence in Ralstonia solanacearum. Appl Environ Microbiol 77: 6426-6432.

38. Brown DG, Swanson JK, Allen C (2007) Two Host-Induced Ralstonia solanacearum Genes, acrA and dinF, Encode Multidrug Efflux Pumps and Contribute to Bacterial Wilt Virulence. Appl Environ Microbiol 73: 2777-2786.

39. Gonzalez A, Plener L, Restrepo S, Boucher C, Genin S (2011) Detection and functional characterization of a large genomic deletion resulting in decreased pathogenicity in Ralstonia solanacearum race 3 biovar 2 strains. Environ Microbiol 13: 3172-3185

40. Plener L, Boistard P, Gonzalez A, Boucher C, Genin S (2012) Metabolic adaptation of Ralstonia solanacearum during plant infection: a methionine biosynthesis case study. PloS One 7: e36877.

41. Wairuri CK, van der Waals JE, van Schalkwyk A, Theron J (2012) Ralstonia solanacearum needs Flp pili for virulence on potato. Mol Plant Microbe Interact 25: 546-556.

42. Flavier AB, Clough SJ, Schell MA, Denny TP (1997) Identification of 3-hydroxypalmitic acid methyl ester as a novel autoregulator controlling virulence in Ralstonia solanacearum. Mol Microbiol 26: 251-259.

43. Schell MA (2000) Control of virulence and pathogenicity genes of Ralstonia solanacearum by an elaborate sensory network. Annu Rev Phytopathol 38 263-292.

44. Salanoubat M, Genin S, Artiguenave F, Gouzy J, Mangenot S, et al. (2002) Genome sequence of the plant pathogen Ralstonia solanacearum. Nature 415 497-502.

45. Gabriel DW, Allen C, Schell M, Denny TP, Greenberg JT, et al. (2006) Identification of open reading frames unique to a select agent: Ralstonia solanacearum Race 3 Biovar 2. Mol Plant Microbe Interact 19: 69-79.

46. Remenant B, Coupat-Goutaland B, Guidot A, Cellier G, Wicker E, et al. (2010) Genomes of three tomato pathogens within the Ralstonia solanacearum species complex reveal significant evolutionary divergence. BMC Genomics 11: 379

47. Remenant B, de Cambiaire JC, Cellier G, Jacobs JM, Mangenot S, et al (2011) Ralstonia syzygii, the Blood Disease Bacterium and some Asian $R$. solanacearum strains form a single genomic species despite divergent lifestyles. PloS One 6: e24356.

48. Li Z, Wu S, Bai X, Liu Y, Lu J, et al. (2011) Genome sequence of the tobacco bacterial wilt pathogen Ralstonia solanacearum. J Bacteriol 193: 6088-6089.

49. Remenant B, Babujee L, Lajus A, Medigue C, Prior P, et al. (2012) Sequencing of K60, type strain of the major plant pathogen Ralstonia solanacearum. J Bacteriol 194: 2742-2743.

50. Xu J, Zheng HJ, Liu L, Pan ZC, Prior P, et al. (2011) Complete genome sequence of the plant pathogen Ralstonia solanacearum strain Po82. J Bacteriol 193: 4261-4262. 